\title{
Finnish records on the genus Inocybe Ecology and distribution of four calciphilous species
}

\author{
JUKKA VAURAS and SEPPO HUHTINEN
}

\begin{abstract}
VAURAS, J. \& HUHTINEN, S. 1986: Finnish records on the genus Inocybe. Ecology and distribution of four calciphilous species. - Karstenia 26: 65-72.

The ecology and distribution of Inocybe bongardii (Weinm.) Quél., I. leucoblema Kühn., I. perlata (Cooke) Sacc., and I. terrigena (Fr.) Kuyp. are treated on the basis of Finnish material. Though variable in colours, most of the material of I. perlata was found to fit excellently with Cooke's original concept. A closer presentation is given of a study area in SW Finland where the calcareous bedrock and emissions from a limestone-processing factory have strongly affected the mycoflora. Heavy fall-out of chalk dust induces production of extremely large fruit bodies in Paxillus involutus (Batsch) Fr. Pluteus exiguus (Pat.) Sacc. and Inocybe amblyspora Kühn. are reported as new to Finland. In addition, many rare species are reported, whose occurrence is in most cases attributable to the calcareous bedrock and calcium fall-out, e.g. Chamaemyces fracidus (Fr.) Donk, Peziza succosa Berk. and Helvella oblongispora Harmaja.
\end{abstract}

Jukka Vauras and Seppo Huhtinen, Department of Biology, University of Turku, SF20500 Turku, Finland

In the town of Parainen, located in the hemiboreal zone ca. $20 \mathrm{~km} \mathrm{SE}$ of Turku (SW Finland), a limestone-processing factory has spread chalk dust over its surroundings for many decades. These deposits, earlier exceeding $2000 \mathrm{~g} / 100 \mathrm{~m}^{2} /$ month, mainly consist of calcium and potash. The emissions have now' decreased, but the long-term effects will be evident for years to come. Owing to the chalk dust, the calcareous rocks and old, abandoned limestone quarries, the area has a luxuriant mycoflora.

The climate at Parainen is fairly oceanic. July is the warmest month, having a mean temperature of $17^{\circ} \mathrm{C}$, and the coldest month is January, with an average of $-5^{\circ} \mathrm{C}$. The annual precipitation is about $600-650 \mathrm{~mm}$ and the growing period (daily mean temperature $\geq$ $+5^{\circ} \mathrm{C}$ ) is among the longest in Finland, ca. 175-180 days (Anon. 1978).

Visiting the surroundings of Parainen yearly during the period 1979-1986, we have encountered numerous rare species, including Pluteus exiguus (Pat.) Sacc. and Inocybe amblyspora Kühn., which are new to Finland, and Chamaemyces fracidus (Fr.) Donk, Peziza succosa Berk. and Helvella oblongispora Harmaja, which have recently been reported as new (Harmaja 1982, Huhtinen \& Vauras 1984). The presence of $C$. fracidus and other rarities clearly reveals the rich character of the mycoflora. This conspicuous fungus has been found in only a few localities in Fennoscandia and the northernmost collection previously originated from Gotland (cf. Huhtinen \& Vauras 1984). The species was first discovered at Parainen in 1981 and fruited again four years later at the same site, close to an abandoned limestone quarry.

Scots pine (Pinus sylvestris) is the dominant tree at most of the sites visited, intermixed mainly with Betula and Picea abies. A continuous and well-developed moss carpet, formed chiefly by Hylocomium splendens, is very typical of these open forests. As this woodland is rather different from the acid pine forests usually occurring in Finland, many rare vascular plants are frequently found. Among the indicators of calcium fall-out are Monotropa hypopitys var. glabra, Saxifraga tridactylites, Listera ovata and Equisetum variegatum. Other characteristic species in the collection sites are Pteridium aquilinum, Hepatica nobilis, Fragaria vesca and Carex digitata.

The most conspicuous element of the mycoflora is Suillus granulatus (L.: Fr.) O. Kuntze, fruiting in thousands; abundant are also Chroogomphus rutilus (Schaeff.: Fr.) O.K. Miller, Russula exalbicans (Pers.) Melzer and Zvára, Lactarius pubescens (Schrad.) Fr. (syn. L. blumii Bon), Tricholoma terreum (Schaeff.: 


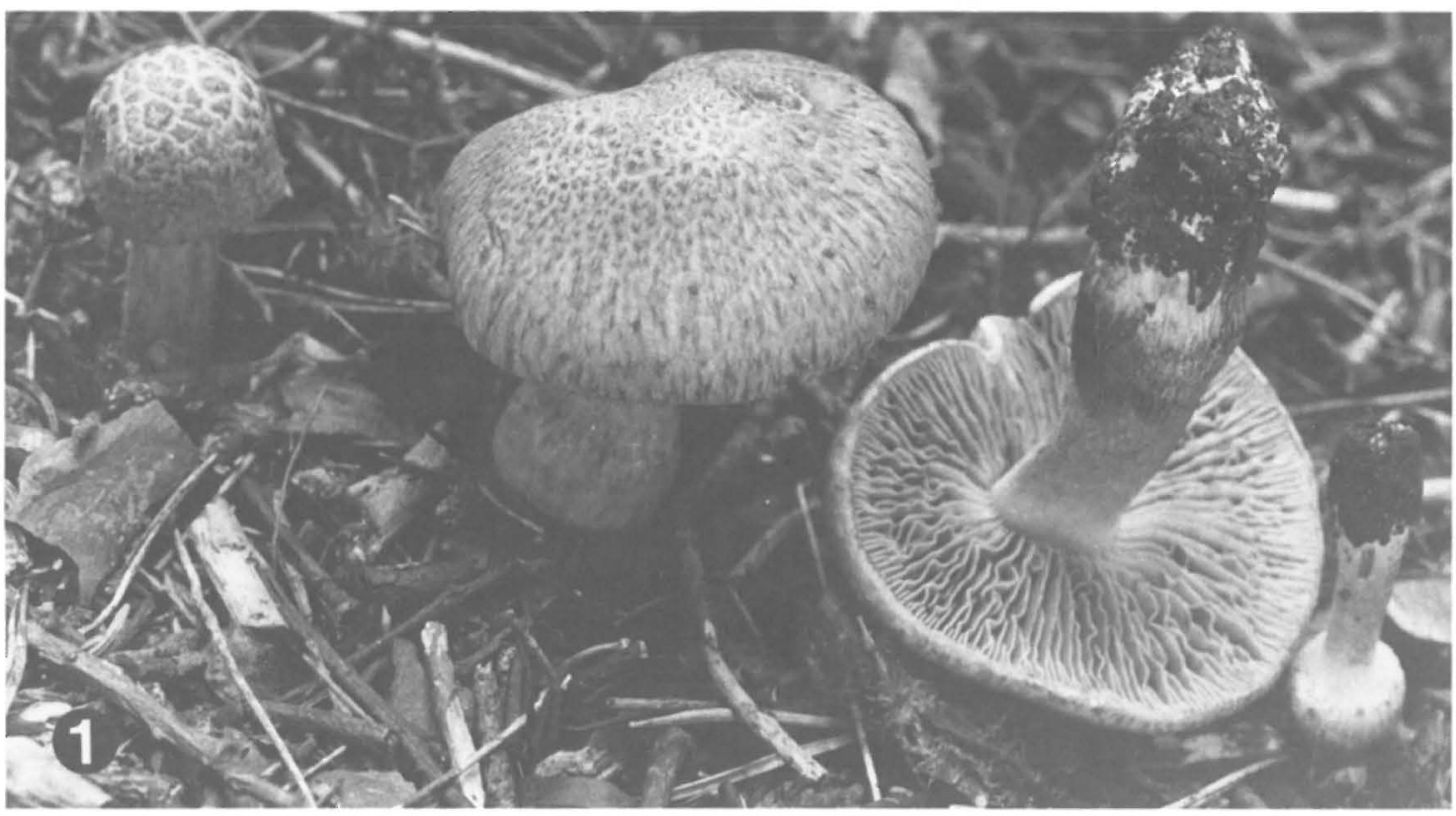

Fig. 1. Inocybe bongardii (Huhtinen \& Vauras 1660F).

Fr.) Kummer, T. scalpturatum (Fr.) Quél. and Helvella crispa Fr. On the other hand, many species typical of ordinary coniferous forests in Finland are lacking, e.g. Lactarius rufus (Scop.: Fr.) Fr., Russula decolorans Fr. and R. paludosa Britz.

The effects of the factory emissions are also seen in the size of the fruit bodies. Paxillus involutus (Batsch) Fr. clearly benefits from heavy fall-out, producing large, extremely lisshy fruit bodies with pilei reaching $35 \mathrm{~cm}$ in diameter. The emissions and the limy soil have also resulted in an abundance of Inocybe Fr., Pluteus Fr. and Pulvinula Boud.

Many uncommon or rare species were encountered during the study years, among them Clitocybe alex-

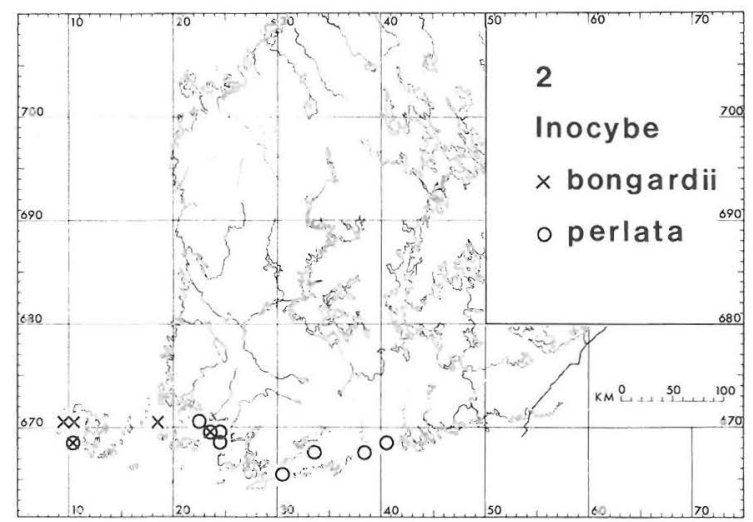

Fig. 2. The distribution of Inocybe bongardii and $I$. perlata in Finland. andri (Gill.) Konr., Tricholoma cingulatum (Fr.) Jacobasch, T. inodermeum (Fr.) Gill., T. aurantium (Schaeff.: Fr.) Ricken, Mycenella salicina (Vel.) Sing. forma bispora Courtec., Hygrophorus gliocyclus Fr., Cortinarius orichalceus (Secr.) Fr., Lactarius citriolens Pouzar and Geastrum quadrifidum Pers.

This paper will deal with four species of Inocybe, a richly represented genus in the forests of Parainen. The descriptions are based on our collections from the area, which are mainly deposited in KUO and TUR. The photographs were taken in situ by J. Vauras. The distribution maps are based on the material in Finnish herbaria. We consider all four species to be more or less calciphilous, since nearly all the collection sites can be classified as calcareous.

\section{Inocybe bongardii (Weinm.) Quél.}

Pileus $1-6.5 \mathrm{~cm}$ in diam, $0.9-2 \mathrm{~cm}$ high, nearly hemispherical when juvenile, later becoming conicoconvex to convex, young margin involute, with a prominent white velum, incised, felted; disc cracked or fibrillose-scaly already when young; juvenile pilei whitish, later light brown, scales and often also the disc darker brown. Lamellae at first white, later greybrown to brown, up to $9 \mathrm{~mm}$ broad, edge pallid and uneven. Stipe $2-10 \mathrm{~cm}$ long, $0.4-2 \mathrm{~cm}$ in diam, of even thickness or basally somewhat wider, coarsely striate, concolorous with pileus, becoming vinaceous when touched; apex white, pruinose (but metuloids absent). Context white, becoming vinaceous. Odour characteristic, fruity, like that of overripe pears. Spores smooth, $11-15(-16.5) \times 6.5-8.5 \mu \mathrm{m}, \mathrm{Q}=(1.5-) 1.7-$ 

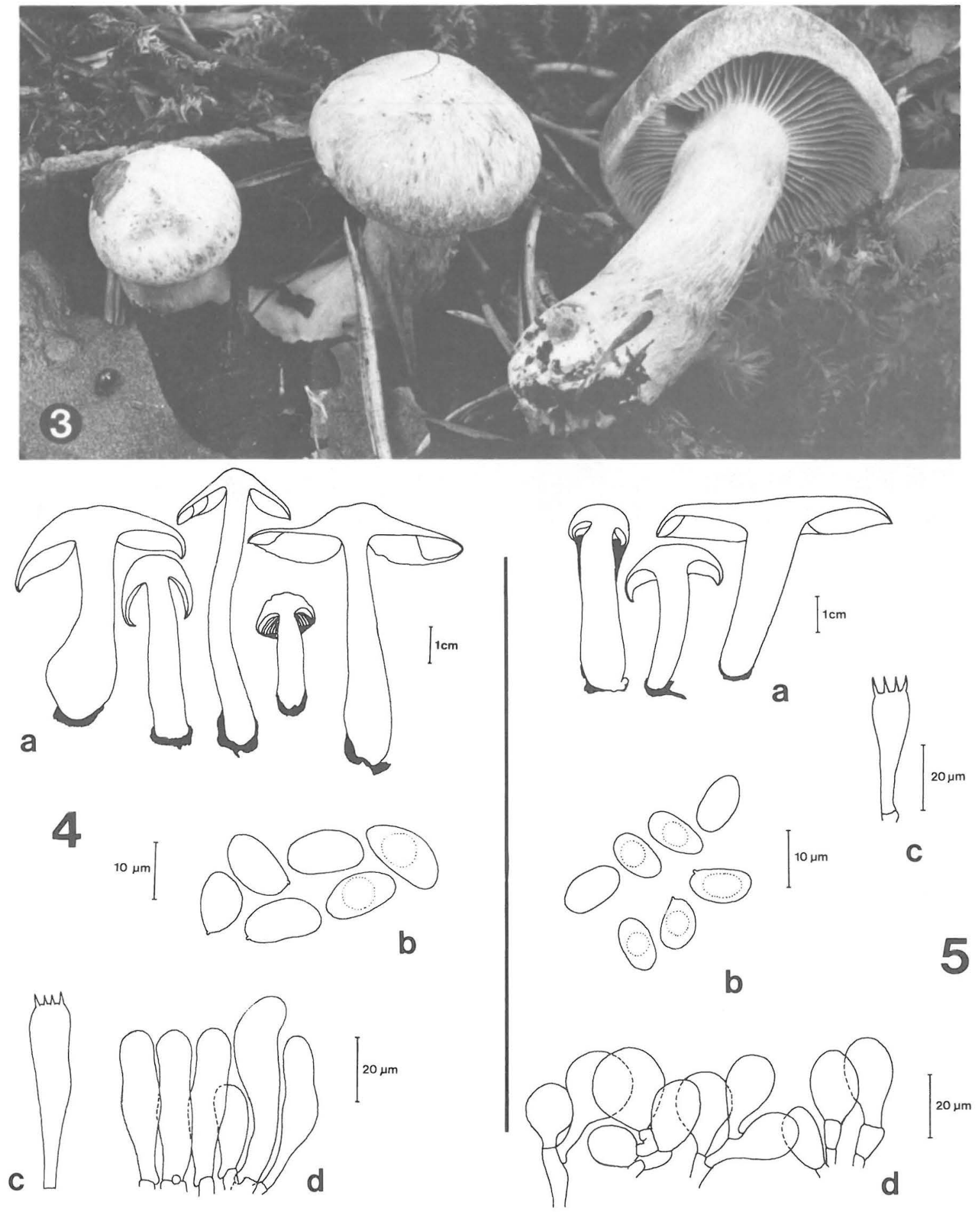

Figs. 3-5. Inocybe bongardii and I. leucoblema. -3: Fruit bodies of I. leucoblema showing the well-developed blematogen layer (Vauras 1877F). -4: I. bongardii. a) Fruit bodies, b) spores, c) basidium, d) cheilocystidia. -5: I. leucoblema. a) Fruit bodies, b) spores, c) basidium, d) cheilocystidia. 


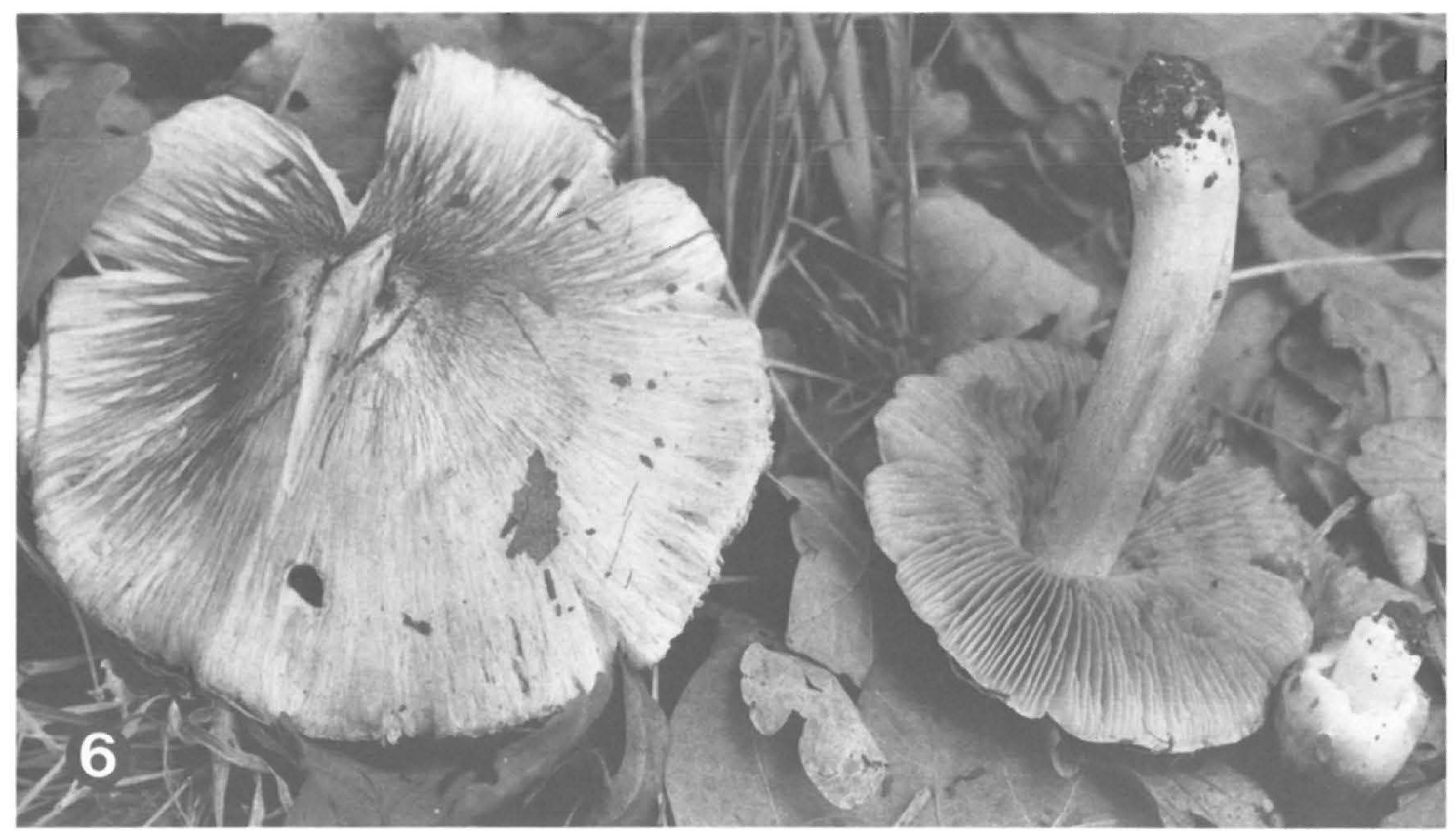

Fig. 6. Inocybe perlata (Vauras 1629F).

\section{$1.9(-2.2)$. Cheilocystidia $29-62 \times 10-15 \mu \mathrm{m}$.}

I. bongardii was first reported from Finland by von Schulmann (1960) and in this country is known only from the hemiboreal zone. It is rare in Sweden as well, but extends to Härjedalen, where it occurs in a luxuriant stand of mountain birch (Jacobsson 1984, Ryman \& Holmåsen 1984). Though widely separated geographically, the specimens from Parainen and those illustrated by Alessio and Rebaudengo (1980) look exactly alike.

All the collection sites are characterized by calcareous bedrock. Perhaps the most typical habitats for $I$. bongardii in Finland are mixed, deciduous, grassherb forests with, e.g., Betula, Salix, Fraxinus and especially Corylus. At Parainen, however, I. bongardii was found at a site lacking Corylus, the only possible mycorrhizal trees being Betula, Picea, Pinus, Frangula alnus and Salix. Compared with the other three species treated in this paper, I. bongardii is not very early in its fruiting; the collections date from early August to late September.

Together with its closest relatives (I. cervicolor (Pers.) Quél., I. geraniodora Favre, I. grata (Weinm.) Bres., I. pisciodora Donadini \& Riousset), the present species is characterized by relatively large and smooth spores, clavate to cylindrical cheilocystidia and the vinaceous reaction of the context. The odour is an important diagnostic character in this group. Enderle and Stangl (1980-1981) even state that only specimens possessing a very strong, sweet odour and collected from among deciduous trees can safely be

\section{called I. bongardii.}

\section{Specimens examined:}

Finland. Aland: Eckerö, 1978 Ulvinen (OULU), 1984 Vauras 1721 (KUO), 1984 Alanen (TUR). Finström, 1974 Raudaskoski (TUR). Lemland, 1981 Korhonen 3991 (H). Mariehamn, 1958 von Schulmann (H). Varsinais-Suomi: Korppoo, 1985 Kosonen (KUO). Parainen, 1962 Kallio (TUR), 1984 Huhtinen \& Vauras 1660F (H, KUO), 1984 Vauras 1765 (KUO), 1985 Huhtinen 85/95 (TUR).

\section{Inocybe leucoblema Kühn.}

- Figs. 3, 5, 8

Pileus $3-7 \mathrm{~cm}$ in diam, convex, margin involute to rather late age; young pilei grey-brown to light brown, later (especially when moist) yellowish-brown to dark brown, typical features being the mixture of brown shades on the pileus and the abundant greyishwhite, occasionally brownish, velum, especially at the margin. Lamellae first light yellowish, later yellowbrown, up to $9 \mathrm{~mm}$ broad, edge pallid. Stipe $2-8 \mathrm{~cm}$ long, $0.5-1.6 \mathrm{~cm}$ in diam, widening towards the base, more rarely uniformly thick or basally tapering, solid, first yellowish and partly covered by a thick velum, later rather coarsely tomentose-fibrillose, yellowbrown, base mostly white. Context yellowish. Odour fungoid. Spores smooth, 9-11.5 (-12) $\times$ 5.5-6.5 (7) $\mu \mathrm{m}, \mathrm{Q}=(1.5-) 1.6-1.9(-2.1)$. Cheilocystidia mostly pyriform, $14-39 \times 10-25 \mu \mathrm{m}$.

There are only slight deviations from the original diagnosis (Kühner 1955). Our material from Parainen has slightly wider spores and cheilocystidia $(9-11.5 \times$ 


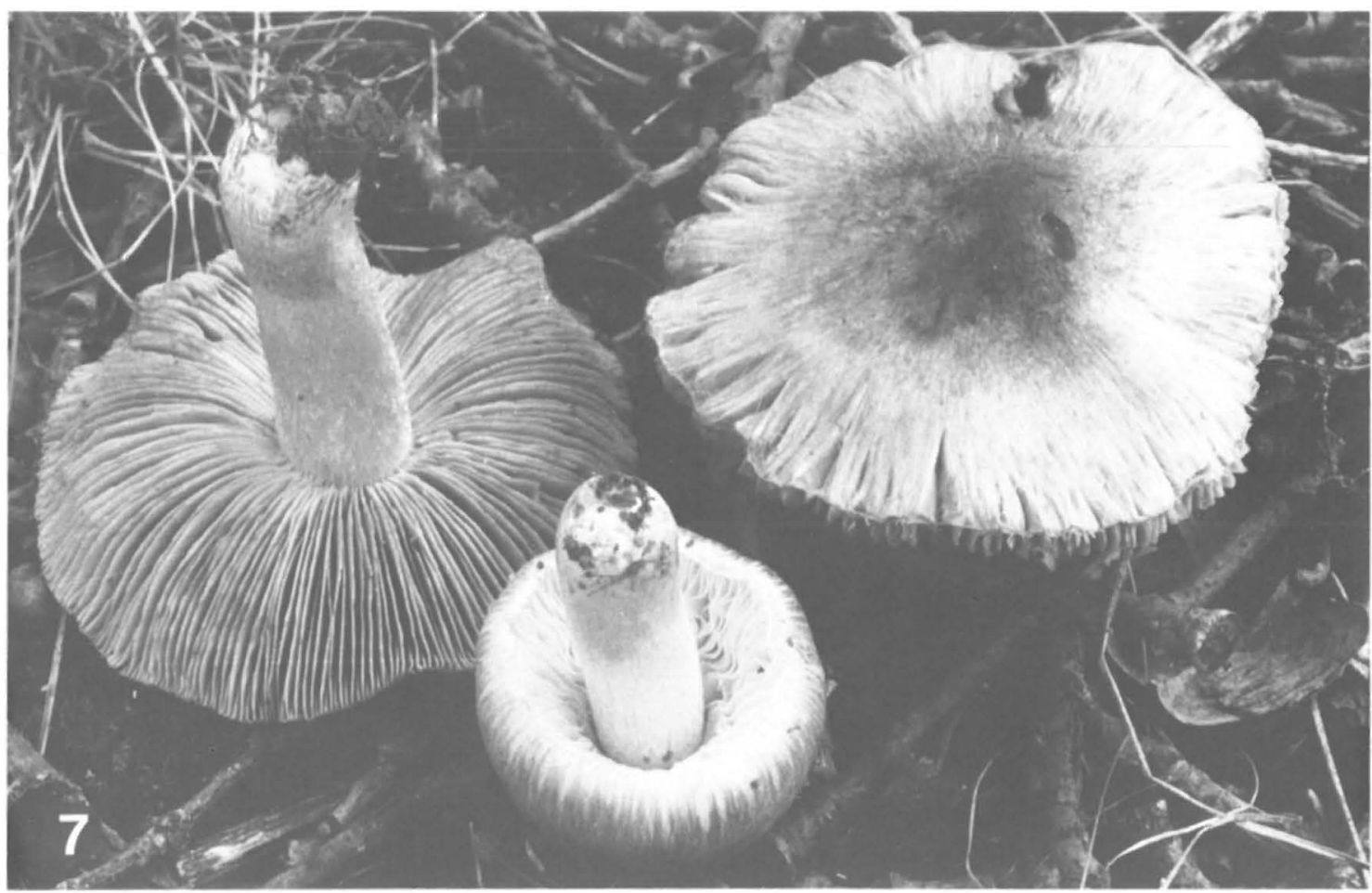

Fig. 7. Paler fruit bodies of Inocybe perlata growing under the same solitary oak as in Fig. 6, 5 m away from 1629F (Vauras 1618F).

5-5.7 $\mu \mathrm{m}$ and 17-36 $\times 7-19 \mu \mathrm{m}$ according to Kühner). The cheilocystidia tend to be narrower in other Finnish collections, but the spore size is uniform. This species was originally reported from forests consisting chiefly of spruce, but has shown a wide ecological spectrum. At Parainen it inhabits coniferous forests with Pinus and Picea, and typical habitats are wooded rock outcrops. I. leucoblema fruits on moss carpets, humus and barren sandy soil (roadsides) from late June to late October.

In northern Finland it is most often found in calcareous, moist spruce forests. It occurs in Lapland (Kilpisjärvi) in rich orohemiarctic mountain birch stands lacking conifers, with an undergrowth of Trollius europaeus and Geranium sylvaticum. A similar habitat was reported from northern Norway by Brandrud and Bendiksen (1984). In Kilpisjärvi the species was also found above the timberline, growing close to Betula nana and Dryas octopetala in an oroarctic (alpine) heath. This habitat was also calcareous, like all the other Finnish localities. Jacobsson (1984) reported I. leucoblema from Sweden from an oroarctic site with $D$. octopetala and dwarfish Salix, and the species is now known even from Svalbard (Huhtinen 1986). Additional records have been made by, e.g. Favre $(1955,1960)$, Bresinsky and Haas (1976) and Ulvinen et al. (1981).

I. leucoblema is closely related to I. dulcamara (Alb. \& Schw.) Kummer and is best distinguished by the abundant velar remnants on the pileus, the lack of cuticular scales and the larger size.

\section{Specimens examined:}

Finland. Varsinais-Suomi: Parainen, 1982 Vauras 1360F (H, KUO), 1982 Korhonen \& Huhtinen 82/624 (H, KUO, TUR), 1983 Vauras 1441 \& Huhtinen (H, KUO), 1983 Korhonen \& Huhtinen 83/410 (TUR), 1984 Huhtinen \& Vauras 1614 (KUO), 1984 Vauras 1628 (H, KUO), 1985 Vauras $1877 \mathrm{~F}$ (KUO), 1986 Vauras 2065 (TUR). Uusimaa: Helsinki, 1984 Saarenoksa 56284, 57184 (H). Etelä-Savo: Lappeenranta, 1984 Vauras 1653 (KUO). Keski-Pohjanmaa: Kälviä, 1983 Storbacka (KUO). Oulun Pohjanmaa: Kiiminki, 1971 Ulvinen (OULU). Koillismaa: Kuusamo, 1975 Ulvinen (OULU), 1982 Ulvinen (OULU), 1982 Ulvinen (OULU). Enontekiön Lappi: Enontekiö, 1979, 1981, 1983 Metsänheimo (OULU), 1985 Vauras 1903, 1925 (KUO).

Inocybe perlata (Cooke) Sacc. - Figs. 2, 6, 7, 11

Pileus $2-12 \mathrm{~cm}$ in diam, first conico-convex, later plano-convex with a blunt umbo, margin often undulating and involute to rather late age; pileus first totally brown (more rarely very pale brown), later with a brown disc and yellowish-brown to almost 


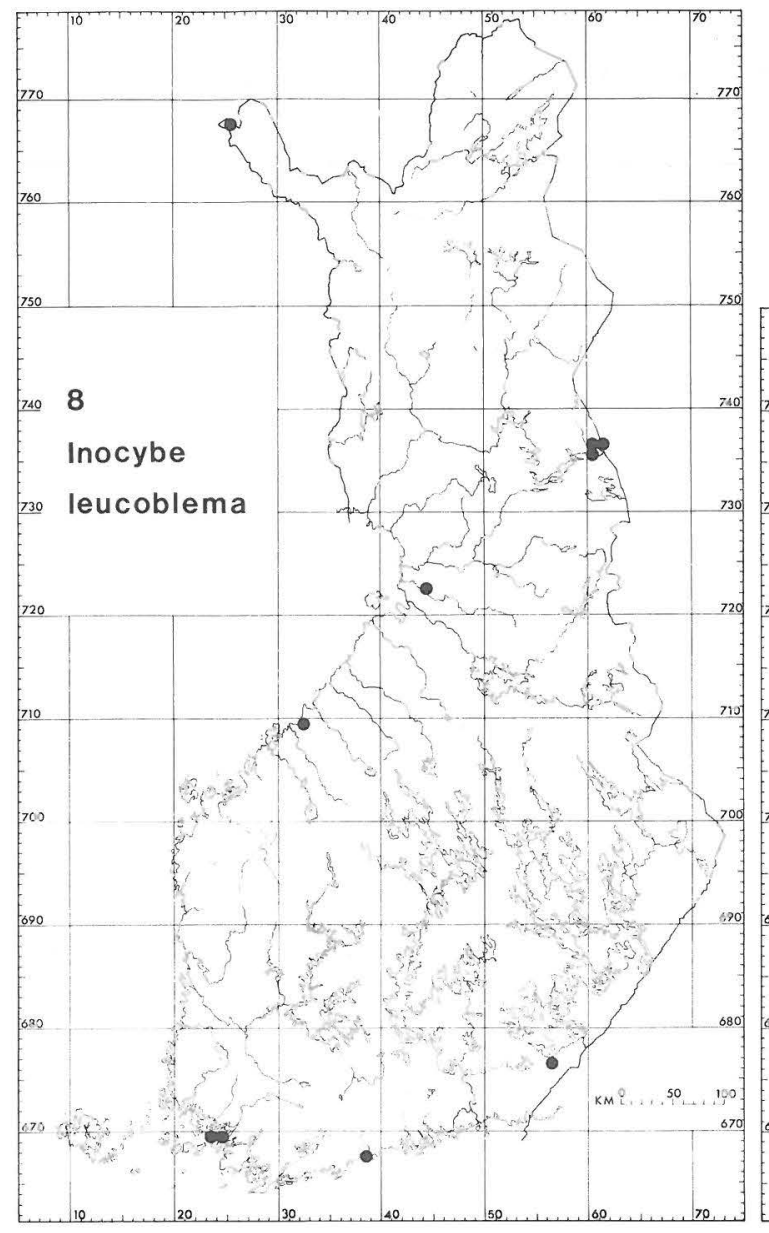

Figs. 8-10. Inocybe leucoblema and I. terrigena. -8: The distribution of 1 . leucoblema in Finland. -9: I. terrigena in Finland. -10: I. terrigena (Vauras 1659F).
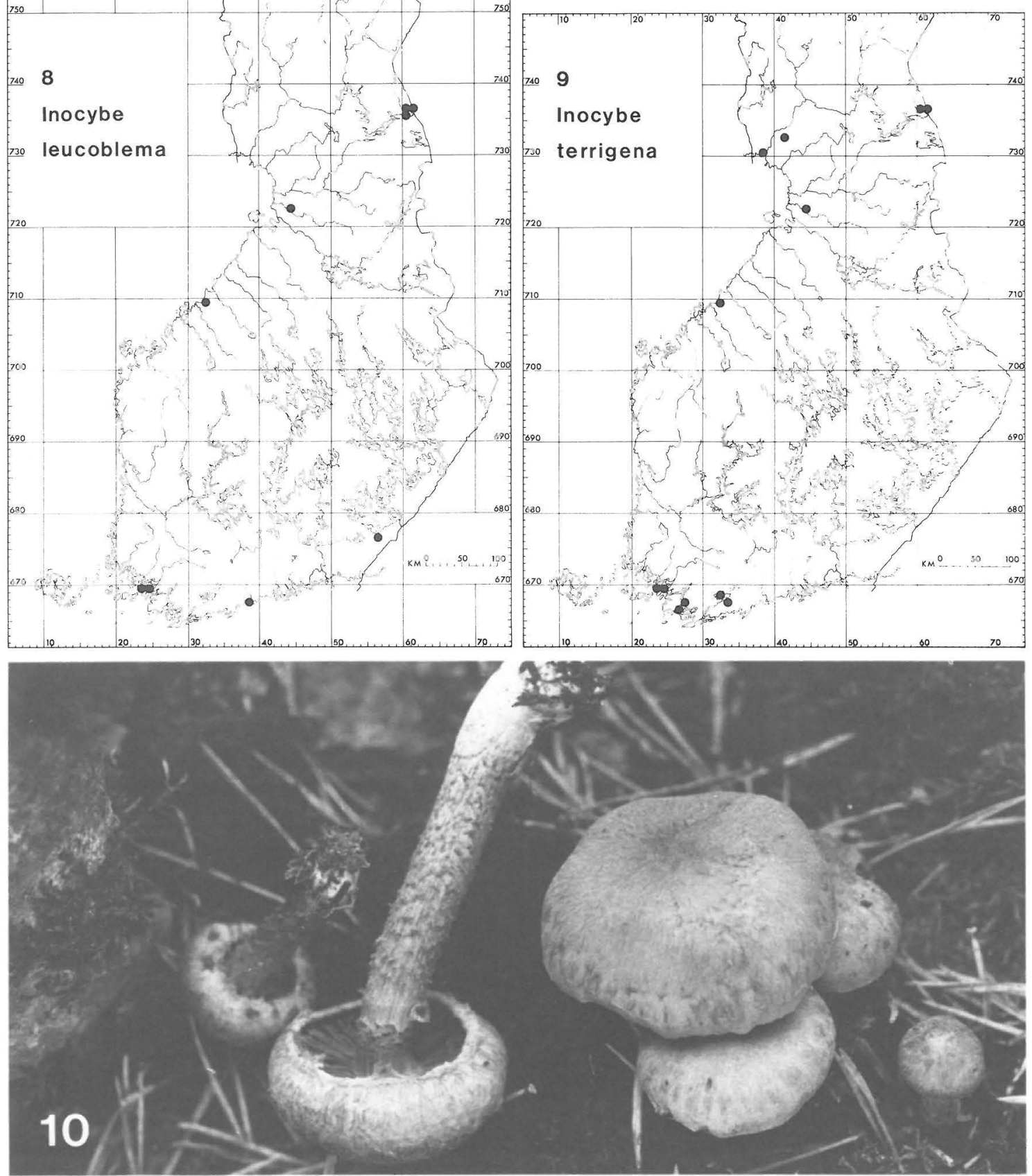

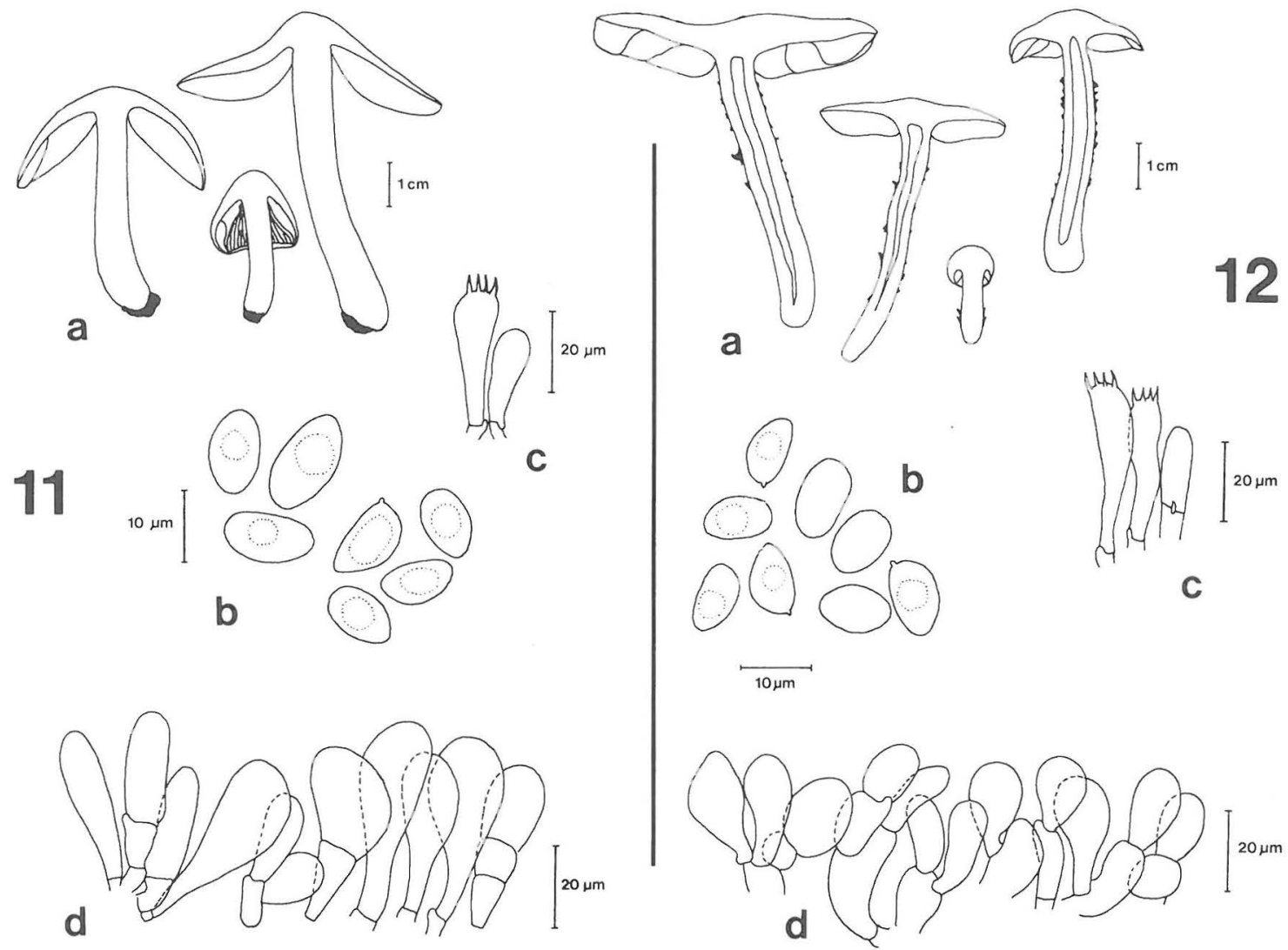

Figs. 11-12. Inocybe perlata and I. terrigena. - 11: I. perlata. a) Fruit bodies, b) spores, c) basidium, and basidiole, d) cheilocystidia. - 10: I. terrigena. a) Fruit bodies, b) spores, c) basidia and basidiole, d) cheilocystidia.

white margin, occasionally also the disc may be whitish due to the presence of velum; velum scanty at margin in young fruit bodies. Lamellae first whitish, later grey-brown to light brown, rather crowded, up to $10 \mathrm{~mm}$ broad, edge pallid. Stipe $2.5-10 \mathrm{~cm}$ long, $0.5-2 \mathrm{~cm}$ in diam, widening slightly towards base, first whitish, becoming brown with age except at the apex, white-fibrillose. Context white, partly brown in stipe. Odour indistinct, not spermatic. Spores smooth, 9.5-14 × 6-7.5 (-8) $\mu \mathrm{m}, \mathrm{Q}=(1.4-) 1.5-1.8$ $(-1.9)$. Cheilocystidia $18-52 \times 10-21 \mu \mathrm{m}$.

In Finland I. perlata is restricted to the hemiboreal zone. All our collections derive from clayey, often bare ground. The species seems to grow at least with Quercus, Betula and Tilia. I. perlata shows a wide phenological range, depending on the year, and can fruit from late June to late September. It was recently reported from Estonia also (Shtshukin 1985).

The closely related $I$. squamata Lange has apparently not been found in Finland: the specimens deposited under that name in Finnish herbaria are here included in I. perlata, although they may have some appressed scales at the disc. Specimens both with and without these scales have been found in two populations. None of the Finnish specimens matches the illustrations of I. squamata in, e.g., Alessio \& Rebaudengo (1980) or Enderle \& Stangl (1980-1981), which show conspicuously squamulose pilei.

We have frequently encountered a paler form of the present fungus, which is close to $I$. obsoleta Romagn. in colour. Though not especially small or slender, these specimens otherwise agree with those illustrated by Alessio and Rebaudengo (1980). In fact, we have observed a continuum from $I$. perlata, as beautifully illustrated by Cooke (1888-1890: Pl. 961), to the present light-coloured form illustrated in Fig. 7. The bulk of our material fits exactly with Cooke's (1883, 1888-1890) concept. The fruit bodies illustrated by Moser and Jülich (1985) differ clearly in being slender, and in their reddish-brown pilei. Furthermore, the typically lighter pileus margin is not evident in Moser's specimens.

Specimens examined:

Finland. Aland: Mariehamn, 1958 von Schulmann (H). 
Varsinais-Suomi: Lohja rural commune, 1984 Vauras 1782 (KUO), 1986 Huhtinen \& Vauras 2087 (TUR), 1986 Vauras 2088 (TUR). Parainen, 1953 von Schulmann (H), 1975 Kallio (TUR), 1977 Korhonen 1704 (H), 1979 Vauras 420F (OULU, TUR), 1982 Vauras 1359, 1369F (KUO), 1982 Vauras $1372 \mathrm{~F}$ (TUR), 1984 Huhtinen \& Vauras 1618F (KUO), 1984 Vauras 1629F (KUO), 1985 Huhtinen 85/96 (KUO, TUR), 1986 Vauras 2095 (TUR). Rymättylä, 1972, 1976, 1977, 1980 Tuomikoski (H), 1979 Väisälä (H). Uusimaa: Helsinki, 1977 Saarenoksa 8877 (H). Sipoo, 1983 Saarenoksa $30883(\mathrm{H})$. Tammisaari, 1961 von Schulmann $(\mathrm{H})$.

\section{Inocybe terrigena (Fr.) Kuyp. - Figs. 9, 10, 12}

Pileus $1.5-7 \mathrm{~cm}$ in diam, yellow-brown, disc smooth to the naked eye, minutely felted under lens, margin with distinct, appressed scales. Lamellae yellowbrown, adnate to subdecurrent, up to $7 \mathrm{~mm}$ broad. Stipe $3.5-10 \mathrm{~cm}$ long, $0.5-1.1 \mathrm{~cm}$ in diam, widening regularly towards the base, hollow, concolorous with the pileus, squamulose below the velar annulus base whitish. Context yellowish. Odour somewhat musty. Spores smooth, 9-11.5 (-13) × 6-7 (-8) $\mu \mathrm{m}, \mathrm{Q}=$ $1.4-1.7(-1.8)$. Cheilocystidia $16-30 \times 9-16 \mu \mathrm{m}$.

This species is easily recognized by its annulate and squamulose stipe. In Central Europe it occurs mainly in moist, calcareous, lower montane forests of Fagus sylvatica and Picea abies, often along small roads reinforced with crushed limestone (Krieglsteiner 1981). In Finland most collections come from the calcareous areas of southwestern and northern Finland, usually from rich, moist stands of Picea abies. Some calcareous habitats in southern Finland are drier, either sandy forests or seemingly poor moss carpets on rocky outcrops. Our observations imply that the species is mycorrhizal not only with spruce, but also with Pinus sylvestris. At Parainen, I. terrigena often shares the sites with I. leucoblema, and is both abundant and widespread. The two species have the same long fruiting period.

\section{Specimens examined:}

Finland. Varsinais-Suomi: Karjalohja, 1979 Harmaja (H). Lohja rural commune, 1984 Vauras 1774 (KUO). Parainen, 1979 Kytövuori $79687(\mathrm{H}), 1981$ Huhtinen 81/175 (KUO, TUR), 1983 Vauras 1583 (KUO), 1984 Huhtinen \& Vauras 1613F (KUO), 1984 Vauras 1659F, 1768 (KUO), 1985 Vauras 2046 (KUO), 1986 Vauras 2064 (TUR). Särkisalo, 1980 Kytövuori 801396 (H). Västanfjärd, 1980 Kytövuori 801189 $(\mathrm{H}), 1982$ Korhonen $4860(\mathrm{H})$. Keski-Pohjanmaa: Kälviä, 1983 Storbacka (KUO). Oulun Pohjanmaa: Kiiminki, 1970 Ohenoja (OULU). Perä-Pohjanmaa: Keminmaa, 1979 Ulvinen (OULU). Tervola, 1978 Ulvinen (OULU). Koillismaa: Kuusamo, 1970 Ulvinen (OULU), 1974 Tuomikoski (H), 1977 Korhonen \& Tuomikoski (H), 1977, 1978 Ulvinen (OULU), 1979 Ohenoja (OULU), 1979 Ulvinen (OULU), 1981 Ohenoja (OULU).

Acknowledgements. Mr Johann Stangl (Augsburg, BRD) is warmly thanked for valuable correspondence. We are grateful to the curators of Finnish herbaria for lending material, and to our friends who have sent us interesting collections. Miss Heli Heikkilä, Lic.Phil. is thanked for valuable practical help. Our thanks are also due to Dr. Tuomo Niemelä for his comments on the manuscript and to Mrs Anna Damström, M.A., for revising the English text.

\section{References}

Alessio, C.L. \& Rebaudengo, E. 1980: Inocybe. - Iconographia Mycologica Ab. Dr. J. Bresadola 29, Suppl. 3. 367 pp., 100 pls. Trento.

Anonymous 1978: Paraisten luonnoninventointi. - 323 pp. Turku.

Brandrud, T.E. \& Bendiksen, E. 1984: Bidrag til sopptloraen i og omkring Junkerdalsura i Øvre Saltland, Nordland. - Agarica 5: 58-85.

Bresinsky, A. \& Haas, H. 1976: Übersicht der in der Bundesrepublik Deutschland beobachteten Blätter- und Röhrenpilze. - Beih. Z. Pilzk. 1: 43-160.

Cooke, M.C. 1883: Handbook of British fungi. - 398 pp. London.

- 1888-1890: Illustrations of British fungi (Hymenomycetes). - London.

Enderle, M. \& Stangl, J. 1980-1981: 4. Beitrag zur Kenntnis der Ulmer Pilzflora: Risspilze (Inocyben). - Mitt. Vereins. Naturwiss. Mathem. Ulm 31: 79-170.

Favre, J. 1955: Les champignons supérieurs de la zone alpine du Parc National Suisse. - Ergeb. Wiss. Untersuch. Schweiz. Nationalparks 5: 1-212, 11 pls.

- 1960: Catalogue descriptif des champignons supérieurs de la zone subalpine du Parc National Suisse. - Ergeb. Wiss. Untersuch. Schweiz. Nationalparks 6: 323-610, 8 pls.

Harmaja, H. 1982: Helvella oblongispora found in Finland. - Karstenia 22: 20.

Huhtinen, S. 1986: New Svalbard fungi. - Manuscript.

Huhtinen, S. \& Vauras, J. 1984: Sienilöytöjä Paraisilta. Sienilehti 36: 51-56.

Jacobsson, S. 1984: Notes on the Agarics in subalpine and alpine areas of western Härjedalen, central Sweden. Windahlia 14: 43-64.

Krieglsteiner, G.J. 1981: Verbreitung und Ökologie 150 ausgewählter Blätter- und Röhrenpilze in der Bundesrepublik Deutschland (Mitteleuropa). - Beih. Z. Mykol. 3: $1-276$.

Kühner, R. 1955: Compléments à la Flore Analytique 6. Inocybe goniosporés et acystidiés. Espèces nouvelles ou critiques. - Bull. Soc. Mycol. France 71: 279-311.

Moser, M. \& Jülich, W. 1985: Farbatlas der Basidiomyceten. - Regensburg.

Ryman, S. \& Holmåsen, I. 1984: Svampar. En fälthandbok. -718 pp. Stockholm.

von Schulmann, O. 1960: Zur Kenntnis der Basidiomyceten Finnlands. - Karstenia 5: 5-99.

Shtshukin, G. 1985: Pervonahodki volokonnits iz Estonii. Fol. Crypt. Est. 22: 1-6.

Ulvinen, T., Ohenoja, E., Ahti, T. \& Alanko, P. 1981: A checklist of the fungi (incl. lichens) of the Koillismaa (Kuusamo) biological province, N.E. Finland. - Oulanka Rep. 2: $1-63$.

Accepted for publication on 7 March 1986 